\title{
Intercultural Communication Between Traders and Buyers in Perbaungan Market
}

\author{
Rita Destiwati \\ Department of Communication \\ Faculty of Communication and Business \\ Universitas Telkom, Bandung, Indonesia \\ ritadetiwati@gmail.com
}

\author{
Junardi Harahap \\ Department of Anthropology \\ Faculty of Social Science and Political Science \\ Universitas Padjadjaran, Bandung, Indonesia \\ junardiharahap@gmail.com
}

\begin{abstract}
Human beings are in constant communication, and always do a lot of activities that has everything to do with communication. In thecommunication process, humans are always in touch with others who have different characters from one to another as well asdiverse cultures. And in communicating, people are constantly in touch with other people that mean the ones who come into contact with other people. The problem in this research is how intercultural communication occurs between vendors and buyers. The method used in this study is a qualitative method of interviews and observations. The results showed that the communication that occurs is related to the communication culture of their culture and the cultures they have is communication culture among market traders that becomes sub culture. Sub culture here can be interpreted as parts of a number of terms in the trade. The terms of the cultureare later developed to expedite the trade and aimed to achieve the goal of gaining profit in the trade.
\end{abstract}

Keywords: Communication, Merchants, Intercultural, Sociology, Anthropology And Buyers.

\section{INTRODUCTION}

The market is a place where communication process takes place to conduct the process of communication that is very concerned about the communication that exists in the market. The market is a process of communication that often even always occurs in a market. The market is an important part of the communication process in the market; communication is an important part in the communitythat performsthe communication process. Communication in behaviors does various things in various communities in the market. Communication in the communication process in the market is an important part that must be considered and addressed in our society. Communication is a significant part done well in the communication. The market is a gathering place in the community where there are many people who do a lot of things that leads to a lot of people who do a lot of things in society.

\section{METHOD RESEARCH}

The method used in this study is a qualitative method approach using observations and interviews, unquestionablyperformed by doing research directly in the market to directly observethe things going on in the market.

\section{LITERATURE REVIEW}

When talking about communication,the literature that covers it is as follows as the views by Darmawan (2013: 247), stating that in buying and selling process, good communication skills are neededto encourage buyers to buy the merchandise traded. It also deals with the culture of consumption as said by Panji (2013: 465) that it is the culture of consumption of the buyer who makes the sales process get good results. Morissan (2013: 173) mentions that cultural process occurs when the selling and buying processtakes place. Cangara (2014: 69) argues thatpersonal communication that occurs between the seller and the buyer enables the communication process. Subur (2006: 110) points out that market isrequired in communication to make it happen to achieve the expected results in communication.

\section{RESULTS AND DISCUSSION}

The market is an area and a region which is very important to do a long process in which the end goal is to gain profit from the buying and selling process.In the market,a number of ways exist to convince people to buysomething.Persuasivelanguages are necessary. The languages used to convince people to buy the merchandise being tradedinclude the following:

Cari apa, Kak!

Untuk siapa, Kak!

Untuk anakku.

Model kayak apa, Kak!

Laki-laki apa perempuan!

Berapa tahun, 5 tahun Kak!

Berapa harganya? 57 ribu

Mahalnya bisakurang tidak... 


\section{Bisalah kurang dikit...}

The process of buying and selling creates the experience of buying and selling. This is particularly important in the buying and selling which is also an important thing in communication is very important to create a very good communication process in a society that is very crowded inside the market. The market is a place where people gather with one purpose, namely to buy something. Furthermore, in the process of buying and selling, there is a communication process that is important to be learned so that others may be affected and want to buy the offered merchandise. It is also a very important process in a communication that is done well. The languages above are very important to be considered in the context of communication that occurs within a society that is so very convenient in the market. In the market itself, there is a process that sometimes leads to the changes in expression that occur in communication, which is very interesting to study and view based on the dimensions of the communication itself.

\section{CONCLUSION}

The conclusion of this study illustrates that communication within the cultural sphere in the market indicates the persuasive languages to get attention of the buyers so that buyers want to buy what is being offered. This communication process is also a process that requires special expertise so that someone is willing to buy what is being sold by the seller. Needlessly to say, it is not easy, because it requires a special expertise in a communication of different cultures.

\section{REFERENCES}

[1] Cangara, H. (2014). PengantarIlmuKomunikasi. Jakarta: PT. RajaGrafindoPersada.

[2] Darmawan, D. (2013). Pendidikan Teknologi Informasi dan. Teoridan Aplikasi. Bandung: PT. Remaja Rosdakarya.

[3] Morissan. (2013). TeoriKomunikasi.Komunikator, Pesan, PercakapandanHubungan (Interpersonal). Bogor: Ghalia Indonesia.
[4] Panji, Y.(2013). Komunikasidan Konstruksi Masyarakat Konsumer (SuatuPerpekstif Cultural Studies). In Budianto, H \& Hamid, F. (ed) (2013) IlmuKomunikasiSekarangdanTantanganMasaDepa n. Jakarta: KencanaPrenanamedia Group.

[5] Subur, A.(2006). SemiotikaKomunikasi. Bandung. PT. RemajaRosdakarya. 